\title{
A New Perspective on the Origin of DNA Double-Strand Breaks and Its Implications for Ageing
}

\author{
Bhabesh Kumar Tripathy ${ }^{1}$ (D), Kavita Pal ${ }^{2}\left(\mathbb{D}\right.$, Snehal Shabrish ${ }^{2}$ and Indraneel Mittra ${ }^{2, *(D)}$ \\ 1 Indian Institute of Science Education and Research (IISER), Tirupati 517507, India; \\ bhabeshkumartripathy@students.iisertirupati.ac.in \\ 2 Tata Memorial Centre, Advanced Centre for Treatment, Research and Education in Cancer (ACTREC) and \\ Homi Bhabha National Institute, Mumbai 410210, India; kavitapal80@gmail.com (K.P.); \\ snehalrm@gmail.com (S.S.) \\ * Correspondence: imittra@actrec.gov.in
}

Citation: Tripathy, B.K.; Pal, K.; Shabrish, S.; Mittra, I. A New Perspective on the Origin of DNA Double-Strand Breaks and Its Implications for Ageing. Genes 2021, 12, 163. https://doi.org/10.3390/ genes12020163

Academic Editor: Karen Mather Received: 11 November 2020 Accepted: 19 January 2021 Published: 26 January 2021

Publisher's Note: MDPI stays neutral with regard to jurisdictional claims in published maps and institutional affiliations.

Copyright: (c) 2021 by the authors. Licensee MDPI, Basel, Switzerland. This article is an open access article distributed under the terms and conditions of the Creative Commons Attribution (CC BY) license (https:/ / creativecommons.org/licenses/by/ $4.0 /)$.

\begin{abstract}
It is estimated that 10-50 DNA double-strand breaks (DSBs) occur in a nucleated human cell per cell cycle. We reviewed the present state of knowledge and hypothesized that the currently accepted mechanisms cannot explain such high frequency of DSBs occurring daily under normal physiological conditions. We propose an alternative model that implicates illegitimate genomic integration into healthy cells of cell-free chromatin ( $\mathrm{cfCh}$ ) particles released from the billions of cells that die in the body every day. Repeated genomic integration of cfCh may have catastrophic consequences for the cell, such as DSBs, their faulty repair by nonhomologous end joining (NHEJ) followed by apoptosis with release of more $\mathrm{cfCh}$ which would integrate into genomes of surrounding cells. This can creates a vicious cycle of cfCh integration, DSBs, NHEJ, and more apoptosis, thereby providing a potential explanation as to why so many billions of cells die in the body on a daily basis. We also recount the recent observation that $\mathrm{cfCh}$ integration and the resulting DSBs activate inflammatory cytokines. This leads us to propose that concurrent DSBs and induction of inflammation occurring throughout life may be the underlying cause of ageing, degenerative disorders, and cancer. Finally, we discuss the prospect that agents that can inactivate/degrade cfCh may hold the key to making healthy ageing a realizable goal.
\end{abstract}

Keywords: free-radicals; cell-free chromatin; apoptosis; DNA damage; NHEJ; mosaicism; inflammation

\section{Introduction}

What causes ageing and age-related diseases? These questions still do not have their final answers [1,2]. DNA double-strand breaks (DSBs) are considered to be the most dangerous among DNA lesions which increase with age [3-5], leading to cell death and cellular senescence [6]. Age-related increase in unrepaired DSBs may be a contributing cause of several degenerative disorders, such as Alzheimer's disease [7], type 2 diabetes [8], cardiovascular disease [9], and cancer [10,11]. What causes DSBs? In this review, we propose that the currently accepted mechanisms may not fully explain the high frequency of DSBs that are seen daily in healthy cells and propose a new mechanism implicating cell-free chromatin ( $\mathrm{cfCh}$ ) particles that are released from billions of cells that die in the body every day. We go on to explain how this mechanism may help to throw new light on ageing and the various age-related disorders mentioned above.

DSBs in DNA occur when phosphodiester linkage between two adjacent nucleotides in each of the strands is cleaved simultaneously, and the sites of cleavage on opposite strands lie sufficiently close to each other. DSBs can be repaired by two pathways-homology dependent repair (HDR), one that is less frequent and less error-prone, and nonhomologous end joining (NHEJ), one that is more frequent and more error-prone [12]. In the HDR pathway, an intact homologous chromosome that shares sequence similarity with the damaged DNA is used as a template for repairing DSBs [12]. In contrast, during repair by NHEJ, 
the two ends are joined by DNA ligases without any need for a homologous sequence. Repair of DSBs by NHEJ can involve incorporation or deletion of random nucleotides into the damaged region, leading to modifications in the original DNA sequence [12]. DSBs constitute a potentially lethal form of DNA lesion and, if left unrepaired, or repaired imperfectly by NHEJ, can result in mutations, chromosomal rearrangements, and cell death Defects in the cell's response to DSBs have been linked to multiple disease conditions, such as neurological disorders [13], diabetes [14], and cancer [15].

It has been reported that 10-50 DSBs occur in a nucleated human cell per cell cycle [16]. However, human tissues and organs consist of both dividing, and non-dividing cells. Most epithelial cells have a rapid turnover rate and have a higher rate of DSBs and mutations which are related to development of cancer [17]. On the other hand, cells such as myocytes, adipocytes, and those of the skin and brain, undergo terminal differentiation and exist in a non-dividing state. The frequency of DSBs has been found to be lower in non-dividing cells $[18,19]$. However, DSBs do accumulate in quiescent cells and increase progressively with age [5]. For example, single-cell whole-genome sequencing has revealed that somatic single-nucleotide variants (sSNV) increase with age in human neuronal cells [20]. DSBs can disrupt neuronal activity and normal functioning of the nervous system and contribute to the development of neurodegenerative disease [21,22]. DSBs in DNA have been proposed to be caused by several exogenous agents, including ionizing radiation, ultraviolet (UV) light, and radiomimetic compounds, as well as by endogenous agents, including free radicals and DNA replication and transcription errors [23]. Radiation damage to cells can occur both by direct and indirect mechanisms [23]. In the direct mode of action, radiation excites nucleotides in the DNA directly, thereby introducing certain chemical modifications and consequently altering DNA structure. In the indirect mode of action, radiation splitsup water molecules in the cytoplasm and other organic molecules in the cell resulting in formation of free radicals, like hydroxyl $(\mathrm{OH} \cdot)$ and peroxyl (ROO.) radicals, which have the potential to induce DSBs. However, significant levels of radiation are not normally present in the environment to explain high levels of DSBs. For example, it is reported that natural background radiation that a human is exposed to on a daily basis is $\approx 0.01 \mathrm{mSv}$ [18]. This value varies across the Earth, but, in general, the impact of radiation on daily introduced DSBs inside our cells is very small. It is well established that ionizing radiation produces 25-40 DSBs per diploid cell per gray [24]. Hence, natural sources of radiation cannot be the reason for multiple DSBs that appear in our cells daily.

Free radicals are normally generated as by-products of cellular metabolism occurring in mitochondria [25], peroxisomes [26], and the endoplasmic reticulum (ER) [27]. At high levels, free radicals can induce oxidative and nitrosative stress that can potentially damage biomolecules, including proteins [28], lipids [29], and DNA [30]. Hydroxyl (OH·) radicals, one of the most damaging free radicals, react with nucleotide bases and deoxyribose sugars and introduce chemical modifications in them, including the formation of abasic sites and generation of single-strand breaks (SSBs) in DNA [31]. These base modifications and singlestrand DNA damage are repaired via the base excision repair pathway [32]. The latter proceeds through the removal of damaged bases, formation of SSBs, and further processing to repair and seal off the damage [32]. It has been shown in instances where two SSBs are present on alternate strands in close proximity, they can be spontaneously converted into DSBs during their repair process [16]. However, hydroxyl radicals have a very short in vivo half-life of approximately $10^{-9} \mathrm{~s}$ [33]; and, once they are produced, they can react only with molecules close to their site of production. Hence, they can, at best, attack mitochondrial DNA but, in all probability, do not make it to the genomic DNA. $\mathrm{H}_{2} \mathrm{O}_{2}$, another toxic species, is said to indirectly damage DNA by producing hydroxyl radicals in presence of transition metal ions (Fenton reaction) or by reacting with superoxide radicals (Haber-Weiss reaction) [34]. However, the availability of transition metal ions in sufficient amounts near the genomic DNA to take part in the Fenton reaction is questionable [35]. It is also not evident if there is ever enough $\mathrm{H}_{2} \mathrm{O}_{2}$ to escape the antioxidant defense system of the cells to damage the genomic DNA [36]. Singlet oxygen $\left({ }^{1} \mathrm{O}_{2}\right)$ is another free radical 
that can induce DNA damage and has been shown to react selectively with guanine moiety in nucleosides and introduce SSBs in plasmid DNA [37]. Currently, there is no evidence of it $\left({ }^{1} \mathrm{O}_{2}\right)$ inducing DSBs in the genomic DNA.

Other endogenous mechanisms by which DSBs may occur are DNA replication and transcription errors. SSBs and DNA crosslinking due to covalent linkage between two nucleotides either within the same strand or between two opposite strands of DNA, referred to as DNA intra-strand and inter-strand crosslinks, respectively, or due to covalent linkage between DNA and proteins can introduce lesions in DNA and interfere in DNA replication. During the latter, DNA polymerase may stall when it encounters these lesions, thereby disrupting the replication fork, leading to formation of DSBs [38-40]. However, this hypothesis may not be applicable to neuronal cells that do not divide, and especially since DSBs in brain increase progressively with age and are linked with neurodegenerative disorders, like Alzheimer's disease [41]. Another hypothesis is the formation of DSBs from $\mathrm{R}$ loops formed during transcription [42]. $\mathrm{R}$ loops are triple stranded nucleic acid structures consisting of a DNA:RNA hybrid structure along with the displaced DNA strand. They are mostly formed during the elongation step of transcription when a portion of nascent RNA transcript re-anneals to its DNA complement. But whether or how R loops cause DSBs is not known [42].

The above review of the literature leads us to conclude that the currently accepted mechanisms cannot explain the high frequency of DSBs that have been reported to occur daily under normal physiological conditions and that new mechanisms to explain DSBs are needed. We provide below one such new mechanism which involves DSBs inflicted by genomic integration of cell-free chromatin ( $\mathrm{cfCh}$ ) particles released from dying cells.

\section{Cell-Free Chromatin: A Continuously Arising Trigger for DSBs}

Several hundred billion to a trillion cells, largely of haematogenous origin, die in the adult human body daily due to normal physiology, and a similar number is regenerated by mitosis to maintain homeostasis [43]. The daily turnover of granulocytes has been reported to be of the order of $120 \times 10^{9}$ cells, that of erythrocytes to be $200 \times 10^{9}$ cells, of platelets to be $150 \times 10^{9}$ cells and of lymphocytes to be $20 \times 10^{9}$ cells [43]. This high rate of cell death on a daily basis occurs primarily by apoptosis which is characterized by condensation and fragmentation of chromatin mediated by endogenous nucleases [44]. Fragmentation and inter-nucleosomal cleavage of DNA leads to formation of oligo-nucleosomes with multiples of 180-200 base pairs [45,46]. A proportion of the nucleosomal fragments (cellfree chromatin, $\mathrm{cfCh}$ ) generated following cell death finds entry into the extra-cellular compartments of the body, including into the circulation [47-49]. Increasing cfCh levels are positively correlated with age [50,51], and elevated blood levels have been reported in many acute and chronic human disorders, including cancer [47,52-61]. cfCh is cleared by the body by several mechanisms, which include: (1) phagocytotic clearance by macrophages [62]; (2) degradation of DNA component of cfCh by DNase I present in circulation [63]; and (3) continuous clearance by the liver resulting in a turnover half-life of cfCh in circulation of $10-15 \min [64,65]$.

\section{1. cfCh Particles in Circulation Inflict DSBs in Healthy Cells by Integrating into Their Genomes}

Chromatinized genes generated by in vitro reconstitution of DNA with histones are known to be efficiently taken up by cells followed by their genomic integration [66]. Although the first report of cfCh in human circulation appeared in 1990 [67], whether they have any patho-physiological role to play in the host has only recently been addressed $[51,68]$. cfCh particles were successfully isolated from sera of cancer patients and healthy volunteers, which upon electron microscopy (EM) examination appeared as particles of heterogeneous sizes $(\sim 10 \mathrm{~nm}>1000 \mathrm{~nm})$ having a beads-on-a-string appearance typical of chromatin. When cfCh particles that were fluorescently dually labeled in their DNA and histones were applied to mouse fibroblast cells, numerous dually labeled fluorescent signals were detected in nuclei of the treated cells with a maximum nuclear uptake reaching at $6 \mathrm{~h}$. Nuclear uptake was 
rapidly followed by their association with host cell chromosomes which led to intense activation of a DNA damage repair response (DDR), which facilitated their incorporation into the host cell genome via a unique mechanism described later in this article. The up-regulated DDR proteins included H2AX, ATM, ATR, MDC-1, P-p53, P-p21, GADD-34, Nibrin, Rad50, MRE-11, DNA-PKcs, and DNA ligase IV. In addition, up-regulated were proteins of the apoptotic pathway, namely JC-1, cytochrome-C, and caspase 3, indicating that DSBs were likely to result in apoptosis of many affected cells [68]. Multiple lines of evidence were advanced to demonstrate that cfCh had truthfully integrated into the genomes of the recipient cells. Fluorescent in situ hybridization (FISH) using human-specific whole genomic and pan-centromeric probes showed multiple human DNA signals in two single cell clones that had been developed from the mouse fibroblast cells that had been treated with cfCh isolated from cancer patients. Next, generation genomic sequencing of the single-cell clones detected tens of thousands of human reads in the mouse cells, while PCR amplification of DNA from them identified multiple human Alu sequences [68].

When cfCh particles isolated from cancer patients were injected intravenously into mice, numerous human DNA signals were detected in nuclei of cells of their vital organs upon analysis by FISH. That genomic integration of $\mathrm{cfCh}$ particles were indeed responsible for DSBs was confirmed by detection of precise co-localization of human FISH signals with those of $\gamma-\mathrm{H} 2 \mathrm{AX}$ in brain cells of mice [68]. Extensive activation of H2AX was also seen in cells of all other vital organs by immunofluorescence analysis. Significantly, cfCh from cancer patients were invariably found to be more active in inducing DSBs than those isolated from healthy volunteers, suggesting a possible role of the former in pathogenesis of cancer. Finally, DSBs induced by $\mathrm{cfCh}$ were abrogated both in vitro and in vivo when concurrently treated with cfCh inactivating agents, namely anti-histone antibody-complexed nanoparticles (CNPs) and/or DNase I [68,69].

\section{2. cfCh Particles Released Locally from Dying Cells Inflict DSBs in Bystander Cells}

Two recent publications have reported that cfCh particles released locally from dying cells can be freely ingested by bystander healthy cells. This was demonstrated by dually labeling Jurkat cells in their DNA and histones with BrdU and CellLight ${ }^{\circledR}$ Histone 2B GFP respectively, followed by treating the labeled cells with ionizing radiation ( $15 \mathrm{~Gy})$. When the fluorescently labeled dying Jurkat cells were co-cultured with mouse fibroblast cells and examined by confocal microscopy, numerous dually labeled fluorescent particles that were released from the dying Jurkat cells were found to have been up-taken by the co-cultured cells to accumulate in their nuclei within $24 \mathrm{~h}[70,71]$. Two single-cell clones were prepared from the co-cultured mouse fibroblast cells and subjected to whole genome sequencing and bioinformatics analyses which detected 209 human Alu elements represented by 15 unique human Alu families when data derived from the two clones were combined. Genomic integration of human cfCh particles led to extensive DSBs and chromosomal aberrations in the mouse cells [71]. Delivery of focused micro-beam irradiation to the umbilical region of mice resulted in intense activation of $\mathrm{H} 2 \mathrm{AX}$ in brain cells, indicating that cfCh released from radiation-induced dying cells can travel to distant organs via the bloodstream to inflict DSBs.

\section{3. cfCh Particles Released from Dying CTCs Inflict DSBs in Distant Organs}

It is well established that circulating tumor cells (CTCs) undergo extensive cell death upon reaching target organs [72,73]. In experiments in which viable mouse melanoma cells that had been fluorescently pre-labeled were injected intravenously into mice, numerous fluorescent $\mathrm{cfCh}$ signals were detected in the nuclei of their vital organs. Immune staining analysis showed precise co-localization of fluorescent $\mathrm{cfCh}$ signals with those of $\gamma$ H2AX [70]. This finding indicated that $\mathrm{cfCh}$ particles released from CTCs that die upon reaching distant organs can integrate into genomes of target cells to inflict DSBs. 


\section{3. cfCh Particles Integrate into Genomes Via a Unique Mechanism to Inflict DSBs}

A unique model by which cfCh particles integrate into genomes of healthy cells has been proposed wherein the sequence of DSBs and activation of DDR are reversed (Figure 1) [68,74].

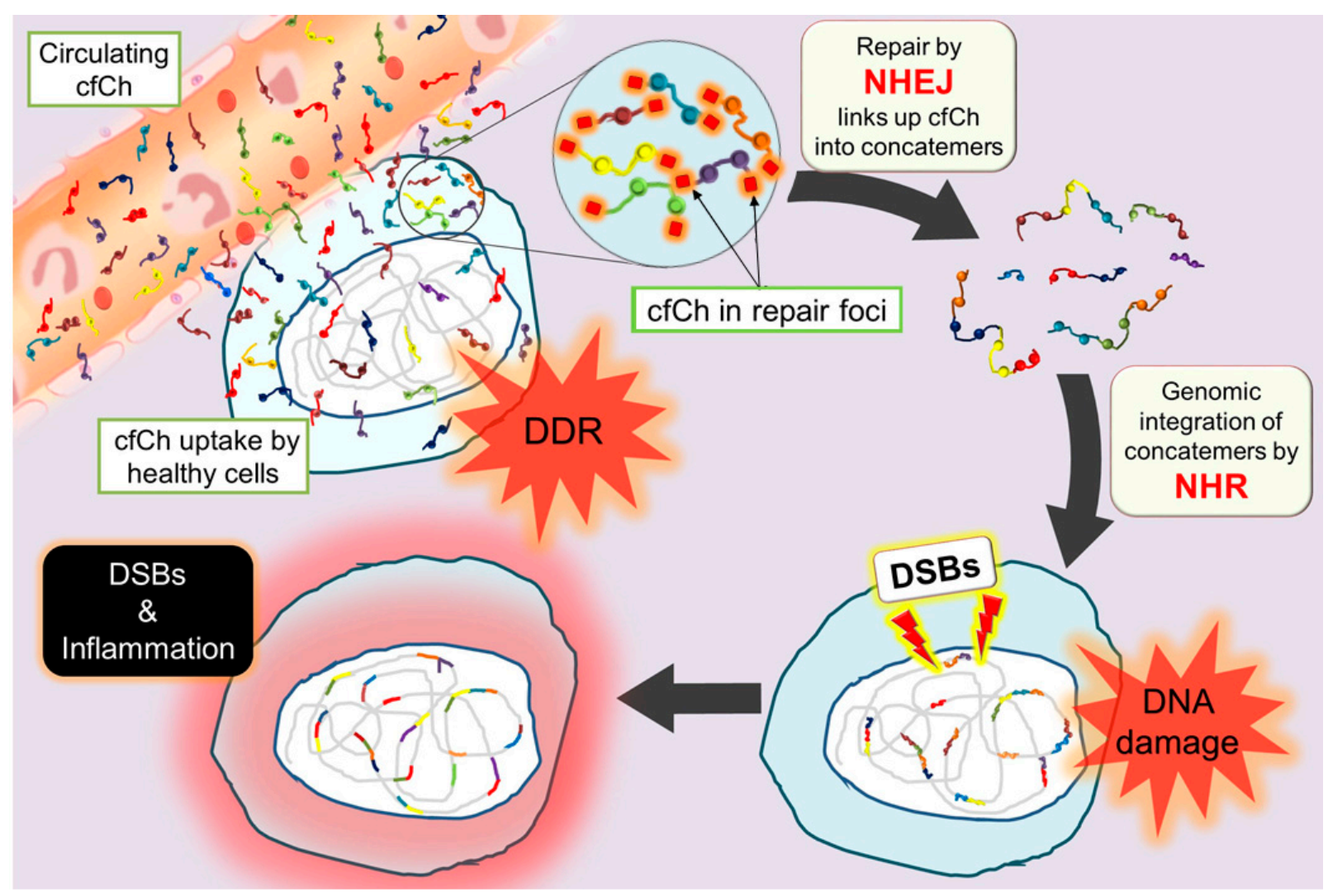

Figure 1. Schematic representation of the unique mechanism by which cell-free chromatin (cfCh) particles integrate into the genome to inflict double-strand breaks (DSBs) and to activate an inflammatory response. NHEJ: nonhomologous end-joining; NHR: nonhomologous recombination. It is to be noted that in this model damage repair response (DDR) precedes DNA damage.

In the classical model, DDR is activated after DSBs have been induced by damaging agents, such as ionizing radiation, $\mathrm{UV}$, and radiomimetic chemicals. According to the proposed model, on the other hand, DDR is prematurely activated prior to DNA damage. Internalized cfCh particles 'deceive' the cell into perceiving them as fragments of its own chromosomes with DSBs at both broken ends, leading the cell to mount a DDR/repair response well before any DNA damage has actually occurred. The DDR activates various repair proteins, especially, DNA PK-cs and DNA ligase IV, which link up the numerous disparate intra-cellular cfCh fragments into concatamers of variable sizes containing a mosaic of discontinuous DNA segments that form new substrates for integration into the host cell genomes. Genomic integration of concatamers occurs via nonhomologues recombination with potentially catastrophic consequences, such as mutations, rearrangements, and various other modifications in the genome. Thus, according to the new model, genomic integration of extraneous cfCh concatamers comprising of a mosaic of DNA segments, which might also include centromeric sequences, may have far-reaching consequences beyond the induction of DSBs. These consequences are likely to include formation of extensive genetic rearrangements and mosaicism, genomic instability, and potentially oncogenic transformation and/or apoptosis of the affected cell [68,74]. Recent reports suggest that genomic integration of cfCh or its concatamers also activate inflammatory cytokines, as discussed later in this article. 


\section{4. cfCh Particles Propel a Vicious Cycle of DSBs, Apoptosis and more DSBs}

In this section, we try to analyze why so many billions of cells die in the body every day? Clearly, DSBs inflicted by integration of cfCh concatamers and their repair by NHEJ may often prove too toxic an assault on the genome which may cause apoptosis of the affected cell. The latter would lead to release of more cfCh particles which may integrate into surrounding bystander cells to trigger a vicious cycle of DSBs followed by imperfect repair by NHEJ and further rounds of apoptosis (Graphical abstract). Perpetuation of this vicious cycle is likely to generate more complex mosaic concatamers which upon genomic integration will progressively escalate further rounds of DSBs, apoptosis and mosaicism of the genome. Cellular apoptosis will also release $\mathrm{cfCh}$ particles into the circulation and perpetuate similar vicious cycles in cells of distant organs, leading to systemic mosaicism. This model may thus help to throw light on the question as to why the somatic genome becomes progressively unstable and mosaic with increasing age [4]. The model also reflects the scale and consequences of day-to-day apoptosis of billions of cells and the vicious cycle that they create to generate progressively increasing mosaicism and genetic instability throughout all cells of the body which would increase with age.

\section{5. cfCh Integration and DSBs Activate Inflammation}

Emerging evidence suggests that DSBs inflicted by cfCh integration into the genome can lead to activation of inflammatory cytokines $[70,71,75,76]$. Co-cultivation of irradiated dying human cancer cells with mouse fibroblasts not only resulted in activation of H2AX, as described above but also to that of multiple inflammatory cytokines in the fibroblast cells. These included the transcription factor NFkB, as well as other cytokines, such as IL-6, TNF- $\alpha$, and IFN- $\gamma$. The inflammatory cytokines were up-regulated concurrently, reaching a maximum at $\sim 6 \mathrm{~h}$, which coincided with the point of maximum activation of H2AX. The interrelationship between cfCh-induced DSBs and inflammation was supported by microarray studies wherein the timing of up-regulation of multiple pathways related to inflammation coincided with those associated with cell cycle and DNA damage. Further confirmation of an association was provided by the finding that treatment with $\mathrm{cfCh}$ inactivating agents not only prevented activation of $\mathrm{H} 2 \mathrm{AX}$, but also that of $\mathrm{NFKB}$ and other inflammatory cytokines [70]. Intravenous injection of dying cancer cells into mice led to activation of both $\mathrm{H} 2 \mathrm{AX}$ and inflammatory cytokines in cells of target organs. Significantly, fluorescent signals of NFKB were found to co-localize with those of $\gamma-\mathrm{H} 2 \mathrm{AX}$ signals. NFkB under normal conditions is known to reside in the cytoplasm; but the violent event of cfCh integration into the genome apparently activates it to translocate to the nucleus particularly to the sites of cfCh integration to co-localize with $\gamma-\mathrm{H} 2 \mathrm{AX}$. These findings have given rise to the suggestion that inflammation may be a direct consequence of cfChinduced DSBs $[75,76]$. Such a proposal is supported by the observation that a direct positive correlation exists between serum levels of $\mathrm{cfCh}$ and inflammatory cytokines in healthy human volunteers [51].

Recently, there have been a number of publications on DNA sensing GMP-AMP synthase-stimulator of interferon genes (cGAS-STING) pathway activation in response to accumulation of DNA in the cytoplasm [77-80]. The latter can occur either following entry of microbes into the cell or due to genomic stress [77]. These, in turn, activate proinflammatory cytokines and trigger an innate immune response [77-79,81]. Activation of cGAS-STING pathway in response to cytoplasmic chromatin fragments (CCF) has also been reported [82-84]. Presence of DNA or CCF in the cytoplasm leads to activation of two downstream pathways, namely the IRF3 pathway, resulting in production of type I interferon, and second, the NFKB pathway, resulting in production of multiple proinflammatory cytokines [77].

Can the uptaken extraneous cfCh particles activate cGAS-STING? Considering our findings discussed above, the possibility that presence of $\mathrm{cfCh}$ particles in the cytoplasm induce NFKB via the cGAS-STING pathway cannot be excluded. However, if it were to be so, an explanation would be needed for the finding of co-localized fluorescent 
signals of NFKB and $\gamma-\mathrm{H} 2 \mathrm{AX}$ precisely at sites of $\mathrm{cfCh}$ integration. The latter would require cytoplasmic $\mathrm{NF} K \mathrm{~B}$ to undergo activation due to $\mathrm{cfCh}$ integration followed by its translocation precisely at the sites of $\mathrm{cfCh}$ integration. Nonetheless, further studies are required to investigate whether $\mathrm{cfCh}$ activation of NFKB occurs via the cGAS-STING pathway or is a direct consequence of DSBs following $\mathrm{cfCh}$ integration?

\section{6. cfCh-Induced DSBs, Somatic Mosaicism, and Inflammation in the Etiology of Ageing, Chronic Diseases, and Cancer}

Rapid advances in next-generation sequencing are revealing that post-zygotic genomes of the same individuals are remarkably heterogeneous. Genome of one cell of the same individual can differ from another in terms of single nucleotide polymorphisms, copy-number variations, insertions, deletions, inversions, translocations, and other structural rearrangements and chromosomal variations $[85,86]$. Genomic mosaicism increases with age and has been shown to be associated with ageing and age-related disorders, such as Alzheimer's disease [7], type 2 diabetes [8], cardiovascular disease [9], and cancer [10,11]. Although, several studies have suggested DSBs to be a primary underlying cause of ageing [3-5], the mechanism(s) by which DSBs are inflicted is not fully understood [5]. More efficient genome maintenance mechanisms in long-lived compared to short-lived organisms have been attributed to more timely and effective expression of genes encoding DDR in the former [87]. Emerging evidence has also implicated defects in DDR signaling to be a key mechanism underlying DNA damage, cell senescence and ageing [88]. DDR activation in senescent cells promotes acquisition of a pro-inflammatory secretory phenotype (SASP), which further elicits DDR and SASP activation in bystander cells, thereby creating a pro-inflammatory environment at the local, and eventually at the systemic level. Therefore, accumulation of cells with an activated DDR probably fuels "inflamm-ageing" that predisposes to development of the many age-related disorders [88].

Our proposal of genomic integration of cfCh particles and/or their concatamers resulting in DSBs followed by imperfect repair by NHEJ occurring throughout life may help to provide an explanation not only for the progressively increasing mosaicism of the ageing genome [4] but also for the multiple degenerative disorders that are associated with ageing. The severe genomic damage will also bring about considerable changes in the epigenome, which may further contribute to the development of ageing-related disease phenotypes [89]. As discussed above, DNA and chromosomal damage will activate an inflammatory response which introduces a new facet to the underlying complexity that contributes to occurrence of the multiple disease conditions [90-94]. Thus, the triple pathologies of DSBs, somatic mosaicism and inflammation, brought about by a common event of cfCh integration into the genome, may provide a unifying model for our understanding of the etiologies of the many chronic disorders that are associated with ageing.

\section{Is it cfCh or cfDNA that Cause DSBs?}

Cell-free DNA (cfDNA) and $\mathrm{cfCh}$ have been shown to have distinct biological activities [95]. Differences exist in cytotoxic activities that are induced individually by cfDNA and when cfDNA is complexed with histones in the form of nucleosomes (cfCh) [95]. In real life, chromosomal condensation and fragmentation following apoptotic cell death results in release of mono- and poly-nucleosomes, and not free DNA [96]. The presence of nucleosomes (cfCh particles) in serum and/or plasma can be directly demonstrated by an ELISA assay that uses antibodies to both DNA and histones [97]. On the other hand, demonstration of cfDNA requires Proteinase-K treatment prior to DNA extraction. Therefore, the possibility that the isolated cfDNA is in effect derived from circulating cfCh cannot be excluded. This is further supported by the several reports of a strong positive correlation between circulating cfCh and cfDNA [98]. Therefore, the question remains as to whether naked DNA exists in circulation [95]? Our recent study of endotoxin-induced sepsis in a mouse model, helps to put this uncertainty to rest by demonstrating that, lipopolysaccharide (LPS)-induced dying host cells release cfCh particles and not free DNA [99]. Although there is much current interest in cfDNA as a biomarker in cancer diagnostics and therapy 
response [100], it is far from clear whether naked DNA circulates as such in the blood as a natural biological molecule. Thus, the biological agent responsible for DSBs is probably cfCh and not cfDNA.

\section{Conclusions}

In this article, we have summarized the currently accepted mechanisms that underlie DSBs and conclude that none of them can fully explain the high frequency of DSBs that occur in nucleated human cells per cell cycle on a daily basis (10-50/cell) under normal physiological conditions. We have proposed an alternative mechanism which involves illegitimate genomic integration into healthy cells of $\mathrm{cfCh}$ particles released from the billions of cells that die in the body every day. Such repeated genomic integration of cfCh particles and repair by NHEJ on a daily basis may account for the high number of DSBs that have been reported in the literature. We have also proposed that premature activation of DDR, leading to intra-cellular ligation of disparate cfCh segments with formation of large and mosaic concatamers may inflict catastrophic damage to the genome upon their genomic integration by nonhomologous recombination. The latter might cause death of the affected cells with release of cfCh particles, leading to a vicious cycle of further cell death propelled by release of more $\mathrm{cfCh}$ particles, thereby providing a possible explanation as to why so many billions of cells die in the body on a daily basis. We have also discussed the novel finding that cfCh integration and DSBs result in activation of inflammatory cytokines, which has led us to propose that concurrent induction of DSBs, genomic instability and inflammation occurring throughout life may be the underlying cause of ageing, the various degenerative disorders, and cancer.

\section{Future Prospects}

Our proposed novel mechanism of induction of DSBs leads to the logical inference that inactivation of cfCh particles may have health benefits, including retardation of ageing. In this context, we have reported that several $\mathrm{cfCh}$ inactivating agents have therapeutic effects $[71,99,101]$. These agents have included (1) nanoparticles complexed with antihistone antibodies which inactivate cfCh particles by binding to histones [69]; (2) DNase I which degrades the DNA component of cfCh particles, thereby depriving it of its damaging effects; and (3) a novel combination of the nutraceuticals resveratrol and metallic copper, which degrades cfCh particles via the medium of free radicals [102]. We have reported that all three $\mathrm{cfCh}$ inactivating/degrading agents can prevent pathologies associated with multiple acute conditions, all of which involve cfCh-induced DSBs and inflammation. For example, these agents can ameliorate toxic side-effects of chemotherapy [101], radiation therapy [71], and sepsis-related cytokine storm and fatality in endotoxin-treated mice [99].

Of the three cfCh inactivating agents, the combination of the nutraceuticals Resveratrol and Copper holds the maximum promise. Resveratrol is a plant polyphenol found in skin of red grapes and berries which has been extensively researched for its antioxidant properties [103]. Metallic copper, likewise, has been widely tested in pre-clinical studies for its potential health benefits [104]. We have discovered that when Resveratrol and Copper are combined, a remarkable reaction is triggered $[71,99,101]$. Resveratrol has the ability to reduce $\mathrm{Cu}$ (II) to $\mathrm{Cu}$ (I) to generate highly unstable free radicals, which can damage cellular organelles, proteins, lipids, DNA, and RNA [28-30]. We have used an oral combination of small quantities of Resveratrol and Copper $(\mathrm{R}-\mathrm{Cu})$ in our pre-clinical studies to demonstrate that free radicals thus generated can degrade cfCh particles, leading to prevention of several pathological conditions associated with cytokine storm $[71,99,101]$. If our preclinical results are replicated in human trials, $\mathrm{R}-\mathrm{Cu}$ may prove to be an ideal agent that might help to retard ageing and age-related degenerative disorders. Clinical trials would be required to investigate if $\mathrm{R}-\mathrm{Cu}$ could make healthy ageing a realizable goal.

Author Contributions: I.M. conceptualized and wrote the manuscript and approved the final draft. B.K.T. and K.P. wrote the manuscript. S.S. prepared the info graphics. All authors have read and agreed to the published version of the manuscript. 
Funding: This study was supported by the Department of Atomic Energy, Government of India, through its grant CTCTMC to Tata Memorial Centre awarded to IM.

Institutional Review Board Statement: Not applicable.

Informed Consent Statement: Not applicable.

Data Availability Statement: Not applicable.

Conflicts of Interest: The authors declare no conflict of interest.

\section{References}

1. Partridge, L.; Deelen, J.; Slagboom, P.E. Facing up to the global challenges of ageing. Nature 2018, 561, 45-56. [CrossRef] [PubMed]

2. Campisi, J.; Kapahi, P.; Lithgow, G.J.; Melov, S.; Newman, J.C.; Verdin, E. From discoveries in ageing research to therapeutics for healthy ageing. Nature 2019, 571, 183-192. [CrossRef] [PubMed]

3. Petr, M.A.; Tulika, T.; Carmona-Marin, L.M.; Scheibye-Knudsen, M. Protecting the Aging Genome. Trends Cell Biol. 2020, 30, 117-132. [CrossRef] [PubMed]

4. Vijg, J.; Dong, X. Pathogenic Mechanisms of Somatic Mutation and Genome Mosaicism in Aging. Cell 2020, 182, 12-23. [CrossRef]

5. White, R.R.; Vijg, J. Do DNA Double-Strand Breaks Drive Aging? Mol. Cell 2016, 63, 729-738. [CrossRef]

6. Tchkonia, T.; Kirkland, J.L. Aging, Cell Senescence, and Chronic Disease. JAMA 2018, 320, 1319-1320. [CrossRef]

7. Dumanski, J.P.; Lambert, J.C.; Rasi, C.; Giedraitis, V.; Davies, H.; Grenier-Boley, B.; Lindgren, C.M.; Campion, D.; Dufouil, C.; Pasquier, F.; et al. Mosaic Loss of Chromosome y in Blood Is Associated with Alzheimer Disease. Am. J. Hum. Genet. 2016, 98, 1208-1219. [CrossRef]

8. Bonnefond, A.; Skrobek, B.; Lobbens, S.; Eury, E.; Thuillier, D.; Cauchi, S.; Lantieri, O.; Balkau, B.; Riboli, E.; Marre, M.; et al. Association between large detectable clonal mosaicism and type 2 diabetes with vascular complications. Nat. Genet. 2013, 45, 1040-1043. [CrossRef]

9. Jaiswal, S.; Fontanillas, P.; Flannick, J.; Manning, A.; Grauman, P.V.; Mar, B.G.; Lindsley, R.C.; Mermel, C.H.; Burtt, N.; Chavez, A.; et al. Age-related clonal hematopoiesis associated with adverse outcomes. N. Engl. J. Med. 2014, 371, $2488-2498$. [CrossRef]

10. Genovese, G.; Kähler, A.K.; Handsaker, R.E.; Lindberg, J.; Rose, S.A.; Bakhoum, S.F.; Chambert, K.; Mick, E.; Neale, B.M.; Fromer, M.; et al. Clonal Hematopoiesis and Blood-Cancer Risk Inferred from Blood DNA Sequence. N. Engl. J. Med. 2014, 371, 2477-2487. [CrossRef]

11. Laurie, C.C.; Laurie, C.A.; Rice, K.; Doheny, K.F.; Zelnick, L.R.; McHugh, C.P.; Ling, H.; Hetrick, K.N.; Pugh, E.W.; Amos, C.; et al. Detectable clonal mosaicism from birth to old age and its relationship to cancer. Nat. Genet. 2012, 44, 642-650. [CrossRef] [PubMed]

12. Lieber, M.R. The mechanism of double-strand DNA break repair by the nonhomologous DNA end-joining pathway. Annu. Rev. Biochem. 2010, 79, 181-211. [CrossRef] [PubMed]

13. Thadathil, N.; Hori, R.; Xiao, J.; Khan, M.M. DNA double-strand breaks: A potential therapeutic target for neurodegenerative diseases. Chromosom. Res. 2019, 27, 345-364. [CrossRef] [PubMed]

14. Tornovsky-Babeay, S.; Dadon, D.; Ziv, O.; Tzipilevich, E.; Kadosh, T.; Schyr-Ben Haroush, R.; Hija, A.; Stolovich-Rain, M.; Furth-Lavi, J.; Granot, Z.; et al. Type 2 diabetes and congenital hyperinsulinism cause DNA double-strand breaks and p53 activity in $\beta$ cells. Cell Metab. 2014, 19, 109-121. [CrossRef]

15. Kasparek, T.R.; Humphrey, T.C. DNA double-strand break repair pathways, chromosomal rearrangements and cancer. Semin. Cell Dev. Biol. 2011, 22, 886-897. [CrossRef]

16. Vilenchik, M.M.; Knudson, A.G. Endogenous DNA double-strand breaks: Production, fidelity of repair, and induction of cancer. Proc. Natl. Acad. Sci. USA 2003, 100, 12871-12876. [CrossRef]

17. Basu, A. DNA Damage, Mutagenesis and Cancer. Int. J. Mol. Sci. 2018, 19, 970. [CrossRef]

18. Bonner, W.M. Low-dose radiation: Thresholds, bystander effects, and adaptive responses. Proc. Natl. Acad. Sci. USA 2003, 100, 4973-4975. [CrossRef]

19. Rothkamm, K.; Lobrich, M. Evidence for a lack of DNA double-strand break repair in human cells exposed to very low x-ray doses. Proc. Natl. Acad. Sci. USA 2003, 100, 5057-5062. [CrossRef]

20. Lodato, M.A.; Rodin, R.E.; Bohrson, C.L.; Coulter, M.E.; Barton, A.R.; Kwon, M.; Sherman, M.A.; Vitzthum, C.M.; Luquette, L.J.; Yandava, C.N.; et al. Aging and neurodegeneration are associated with increased mutations in single human neurons. Science 2018, 359, 555-559. [CrossRef]

21. Kulkarni, A.; Wilson, D.M. The Involvement of DNA-Damage and -Repair Defects in Neurological Dysfunction. Am. J. Hum. Genet. 2008, 82, 539-566. [CrossRef] [PubMed]

22. Rass, U.; Ahel, I.; West, S.C. Defective DNA Repair and Neurodegenerative Disease. Cell 2007, 130. [CrossRef] [PubMed]

23. Desouky, O.; Ding, N.; Zhou, G. Targeted and non-targeted effects of ionizing radiation. J. Radiat. Res. Appl. Sci. 2015, 8, 247-254. [CrossRef]

24. Yang, N.; Galick, H.; Wallace, S.S. Attempted base excision repair of ionizing radiation damage in human lymphoblastoid cells produces lethal and mutagenic double strand breaks. DNA Repair (Amst.) 2004, 3, 1323-1334. [CrossRef] [PubMed] 
25. Cadenas, E.; Boveris, A.; Ragan, C.I.; Stoppani, A.O.M. Production of superoxide radicals and hydrogen peroxide by NADHubiquinone reductase and ubiquinol-cytochrome $\mathrm{c}$ reductase from beef-heart mitochondria. Arch. Biochem. Biophys. 1977, 180, 248-257. [CrossRef]

26. De Duve, C.; Baudhuin, P. Peroxisomes (microbodies and related particles). Physiol. Rev. 1966, 46, 323-357. [CrossRef]

27. Snezhkina, A.V.; Kudryavtseva, A.V.; Kardymon, O.L.; Savvateeva, M.V.; Melnikova, N.V.; Krasnov, G.S.; Dmitriev, A.A. ROS Generation and Antioxidant Defense Systems in Normal and Malignant Cells. Oxid. Med. Cell. Longev. 2019, 2019, 1-17. [CrossRef]

28. Stadtman, E.R.; Levine, R.L. Protein oxidation. Ann. N. Y. Acad. Sci. 2000, 899, 191-208. [CrossRef]

29. Ylä-Herttuala, S. Oxidized LDL and atherogenesis. Ann. N. Y. Acad. Sci. 1999, 874, 134-137. [CrossRef]

30. Marnett, L.J. Oxyradicals and DNA damage. Carcinogenesis 2000, 21, 361-370. [CrossRef]

31. Dizdaroglu, M.; Jaruga, P.; Birincioglu, M.; Rodriguez, H. Free radical-induced damage to DNA: Mechanisms and measurement 1,2 1This article is part of a series of reviews on "Oxidative DNA Damage and Repair." The full list of papers may be found on the homepage of the journal. 2Guest Editor: Miral Dizdaroglu. Free Radic. Biol. Med. 2002, 32, 1102-1115. [CrossRef]

32. Hegde, M.L.; Hazra, T.K.; Mitra, S. Early steps in the DNA base excision/single-strand interruption repair pathway in mammalian cells. Cell Res. 2008, 18, 27-47. [CrossRef] [PubMed]

33. Pryor, W.A. Oxy-radicals and related species: Their formation, lifetimes, and reactions. Annu. Rev. Physiol. 1986, 48, 657-667. [CrossRef] [PubMed]

34. Halliwell, B.; Gutteridge, J.M.C. Role of free radicals and catalytic metal ions in human disease: An overview. Methods Enzymol. 1990, 186, 1-85. [CrossRef]

35. Kakhlon, O.; Cabantchik, Z.I. The labile iron pool: Characterization, measurement, and participation in cellular processes. Free Radic. Biol. Med. 2002, 33, 1037-1046. [CrossRef]

36. Di Marzo, N.; Chisci, E.; Giovannoni, R. The Role of Hydrogen Peroxide in Redox-Dependent Signaling: Homeostatic and Pathological Responses in Mammalian Cells. Cells 2018, 7, 156. [CrossRef]

37. Wefers, H.; Schulte-Frohlinde, D.; Sies, H. Loss of transforming activity of plasmid DNA (pBR322) in E. coli caused by singlet molecular oxygen. FEBS Lett. 1987, 211, 49-52. [CrossRef]

38. Kuzminov, A. Single-strand interruptions in replicating chromosomes cause double-strand breaks. Proc. Natl. Acad. Sci. USA 2001, 98, 8241-8246. [CrossRef]

39. Vare, D.; Groth, P.; Carlsson, R.; Johansson, F.; Erixon, K.; Jenssen, D. DNA interstrand crosslinks induce a potent replication block followed by formation and repair of double strand breaks in intact mammalian cells. DNA Repair (Amst.) 2012, 11, 976-985. [CrossRef]

40. Reardon, J.T.; Cheng, Y.; Sancar, A. Repair of DNA-Protein Cross-links in Mammalian Cells. Cell Cycle 2006, 5, 1366-1370. [CrossRef]

41. Shanbhag, N.M.; Evans, M.D.; Mao, W.; Nana, A.L.; Seeley, W.W.; Adame, A.; Rissman, R.A.; Masliah, E.; Mucke, L. Early neuronal accumulation of DNA double strand breaks in Alzheimer's disease. Acta Neuropathol. Commun. 2019, 7, 1-18. [CrossRef] [PubMed]

42. Aguilera, A.; García-Muse, T. R Loops: From Transcription Byproducts to Threats to Genome Stability. Mol. Cell 2012, 46, 115-124. [CrossRef] [PubMed]

43. Fliedner, T.M.; Graessle, D.; Paulsen, C.; Reimers, K. Structure and function of bone marrow hemopoiesis: Mechanisms of response to ionizing radiation exposure. Cancer Biother. Radiopharm. 2002, 17, 405-426. [CrossRef] [PubMed]

44. Kerr, J.F.R.; Wyllie, A.H.; Currie, A.R. Apoptosis: A basic biological phenomenon with wide-ranging implications in tissue kinetics. Br. J. Cancer 1972, 26, 239-257. [CrossRef]

45. Sakahira, H.; Enari, M.; Nagata, S. Cleavage of CAD inhibitor in CAD activation and DNA degradation during apoptosis. Nature 1998, 391, 96-99. [CrossRef]

46. Wyllie, A.H. Glucocorticoid-induced thymocyte apoptosis is associated with endogenous endonuclease activation. Nature 1980, 284, 555-556. [CrossRef]

47. Zeerleder, S.; Zwart, B.; Wuillemin, W.A.; Aarden, L.A.; Groeneveld, A.B.J.; Caliezi, C.; Van Nieuwenhuijze, A.E.M.; Van Mierlo, G.J.; Eerenberg, A.J.M.; Lämmle, B.; et al. Elevated nucleosome levels in systemic inflammation and sepsis. Crit. Care Med. 2003, 31, 1947-1951. [CrossRef]

48. Van Der Vaart, M.; Pretorius, P.J. The origin of circulating free DNA. Clin. Chem. 2007, 53, 2215. [CrossRef]

49. Suzuki, N.; Kamataki, A.; Yamaki, J.; Homma, Y. Characterization of circulating DNA in healthy human plasma. Clin. Chim. Acta 2008, 387, 55-58. [CrossRef]

50. Jylhävä, J.; Kotipelto, T.; Raitala, A.; Jylhä, M.; Hervonen, A.; Hurme, M. Aging is associated with quantitative and qualitative changes in circulating cell-free DNA: The Vitality 90+ study. Mech. Ageing Dev. 2011, 132, 20-26. [CrossRef]

51. Mittra, I.; Nair, N.K.; Mishra, P.K. Nucleic acids in circulation: Are they harmful to the host? J. Biosci. 2012, 37, 301-312. [CrossRef] [PubMed]

52. Holdenrieder, S.; Stieber, P.; Bodenmüller, H.; Busch, M.; Fertig, G.; Fürst, H.; Schalhorn, A.; Schmeller, N.; Untch, M.; Seidel, D. Nucleosomes in serum of patients with benign and malignant diseases. Int. J. Cancer 2001, 95, 114-120. [CrossRef]

53. Zhong, X.Y.; Gebhardt, S.; Hillermann, R.; Tofa, K.C.; Holzgreve, W.; Hahn, S. Circulatory nucleosome levels are significantly increased in early and late-onset preeclampsia. Prenat. Diagn. 2005, 25, 700-703. [CrossRef] [PubMed] 
54. Trejo-Becerril, C.; Pérez-Cárdenas, E.; Treviño-Cuevas, H.; Taja-Chayeb, L.; García-López, P.; Segura-Pacheco, B.; Chávez-Blanco, A.; Lizano-Soberon, M.; González-Fierro, A.; Mariscal, I.; et al. Circulating nucleosomes and response to chemotherapy: An in vitro, in vivo and clinical study on cervical cancer patients. Int. J. Cancer 2003, 104, 663-668. [CrossRef]

55. Johansson, P.I.; Windeløv, N.A.; Rasmussen, L.S.; Sørensen, A.M.; Ostrowski, S.S. Blood levels of histone-complexed DNA fragments are associated with coagulopathy, inflammation and endothelial damage early after trauma. J. Emergencies Trauma Shock 2013, 6, 171-175. [CrossRef]

56. Geiger, S.; Holdenrieder, S.; Stieber, P.; Hamann, G.F.; Bruening, R.; Ma, J.; Nagel, D.; Seidel, D. Nucleosomes in serum of patients with early cerebral stroke. Cerebrovasc. Dis. 2006, 21, 32-37. [CrossRef]

57. Helseth, R.; Solheim, S.; Arnesen, H.; Seljeflot, I.; Opstad, T.B. The Time Course of Markers of Neutrophil Extracellular Traps in Patients Undergoing Revascularisation for Acute Myocardial Infarction or Stable Angina Pectoris. Mediat. Inflamm. 2016, 2016, 1-3. [CrossRef]

58. Butt, A.N.; Shalchi, Z.; Hamaoui, K.; Samadhan, A.; Powrie, J.; Smith, S.; Janikoun, S.; Swaminathan, R. Circulating nucleic acids and diabetic complications. In Proceedings of the Annals of the New York Academy of Sciences; Blackwell Publishing Inc.: Malden, MA, USA, 2006; Volume 1075, pp. 258-270.

59. Penttilä, A.K.; Rouhiainen, A.; Kylänpää, L.; Mustonen, H.; Puolakkainen, P.; Rauvala, H.; Repo, H. Circulating nucleosomes as predictive markers of severe acute pancreatitis. J. Intensive Care 2016, 4, 14. [CrossRef]

60. Faria, L.C.; Andrade, A.M.F.; Trant, C.G.M.C.; Lima, A.S.; Machado, P.A.B.; Porto, R.D.; Andrade, M.V.M. Circulating levels of High-mobility group box 1 protein and nucleosomes are associated with outcomes after liver transplant. Clin. Transplant. 2020, 34, e13869. [CrossRef]

61. Van Montfoort, M.L.; Stephan, F.; Lauw, M.N.; Hutten, B.A.; Van Mierlo, G.J.; Solati, S.; Middeldorp, S.; Meijers, J.C.M.; Zeerleder, S. Circulating nucleosomes and neutrophil activation as risk factors for deep vein thrombosis. Arterioscler. Thromb. Vasc. Biol. 2013, 33, 147-151. [CrossRef]

62. Savill, J. CELL BIOLOGY: Eat Me or Die. Science 2003, 302, 1516-1517. [CrossRef] [PubMed]

63. Tamkovich, S.N.; Cherepanova, A.V.; Kolesnikova, E.V.; Rykova, E.Y.; Pyshnyi, D.V.; Vlassov, V.V.; Laktionov, P.P. Circulating DNA and DNase activity in human blood. Ann. N. Y. Acad. Sci. 2006, 1075, 191-196. [CrossRef] [PubMed]

64. Gauthier, V.J.; Tyler, L.N.; Mannik, M. Blood clearance kinetics and liver uptake of mononucleosomes in mice. J. Immunol. 1996, 156, 1151-1156. [PubMed]

65. Du Clos, T.W.; Volzer, M.A.; Hahn, F.F.; Xiao, R.; Mold, C.; Searles, R.P. Chromatin clearance in C57B1/10 mice: Interaction with heparan sulphate proteoglycans and receptors on Kupffer cells. Clin. Exp. Immunol. 1999, 117, 403-411. [CrossRef]

66. Wagstaff, K.M.; Fan, J.Y.; De Jesus, M.A.; Tremethick, D.J.; Jans, D.A. Efficient gene delivery using reconstituted chromatin enhanced for nuclear targeting. FASEB J. 2008, 22, 2232-2242. [CrossRef]

67. Rumore, P.M.; Steinman, C.R. Endogenous circulating DNA in systemic lupus erythematosus. Occurrence as multimeric complexes bound to histone. J. Clin. Investig. 1990, 86, 69-74. [CrossRef]

68. Mittra, I.; Kumar Khare, N.; Venkata Raghuram, G.; Chaubal, R.; Khambatti, F.; Gupta, D.; Gaikwad, A.; Prasannan, P.; Singh, A.; Iyer, A.; et al. Circulating nucleic acids damage DNA of healthy cells by integrating into their genomes. J. Biosci. 2015, 40, 91-111. [CrossRef]

69. Rekha, M.R.; Pal, K.; Bala, P.; Shetty, M.; Mittra, I.; Bhuvaneshwar, G.S.; Sharma, C.P. Pullulan-histone antibody nanoconjugates for the removal of chromatin fragments from systemic circulation. Biomaterials 2013, 34, 6328-6338. [CrossRef]

70. Mittra, I.; Samant, U.; Sharma, S.; Raghuram, G.V.; Saha, T.; Tidke, P.; Pancholi, N.; Gupta, D.; Prasannan, P.; Gaikwad, A.; et al. Cell-free chromatin from dying cancer cells integrate into genomes of bystander healthy cells to induce DNA damage and inflammation. Cell Death Discov. 2017, 3, 1-14. [CrossRef]

71. Kirolikar, S.; Prasannan, P.; Raghuram, G.V.; Pancholi, N.; Saha, T.; Tidke, P.; Chaudhari, P.; Shaikh, A.; Rane, B.; Pandey, R.; et al. Prevention of radiation-induced bystander effects by agents that inactivate cell-free chromatin released from irradiated dying cells. Cell Death Dis. 2018, 9, 1142. [CrossRef]

72. Fidler, I.J. Metastasis: Quantitative analysis of distribution and fate of tumor emboli labeled with 125l-5-lodo-2'-deoxyuridine. J. Natl. Cancer Inst. 1970, 45, 773-782. [CrossRef] [PubMed]

73. Kim, J.W.; Wong, C.W.; Goldsmith, J.D.; Song, C.; Fu, W.; Allion, M.B.; Herlyn, M.; Al-Mehdi, A.B.; Muschel, R.J. Rapid apoptosis in the pulmonary vasculature distinguishes non-metastatic from metastatic melanoma cells. Cancer Lett. 2004, 213, 203-212. [CrossRef] [PubMed]

74. Raghuram, G.V.; Chaudhary, S.; Johari, S.; Mittra, I. Illegitimate and repeated genomic integration of cell-free chromatin in the aetiology of somatic mosaicism, ageing, chronic diseases and cancer. Genes 2019, 10, 407. [CrossRef] [PubMed]

75. Chaudhary, S.; Mittra, I. Cell-free chromatin: A newly described mediator of systemic inflammation. J. Biosci. 2019, 44, 1-6. [CrossRef]

76. Chaudhary, S.; Raghuram, G.V.; Mittra, I. Is inflammation a direct response to dsDNA breaks? Mutat. Res. Fundam. Mol. Mech. Mutagen. 2018, 808, 48-52. [CrossRef]

77. Paludan, S.R.; Bowie, A.G. Immune Sensing of DNA. Immunity 2013, 38, 870-880. [CrossRef]

78. Sun, L.; Wu, J.; Du, F.; Chen, X.; Chen, Z.J. Cyclic GMP-AMP synthase is a cytosolic DNA sensor that activates the type I interferon pathway. Science 2013, 339, 786-791. [CrossRef] 
79. Härtlova, A.; Erttmann, S.F.; Raffi, F.A.M.; Schmalz, A.M.; Resch, U.; Anugula, S.; Lienenklaus, S.; Nilsson, L.M.; Kröger, A.; Nilsson, J.A.; et al. DNA Damage Primes the Type I Interferon System via the Cytosolic DNA Sensor STING to Promote Anti-Microbial Innate Immunity. Immunity 2015, 42, 332-343. [CrossRef]

80. Motwani, M.; Pesiridis, S.; Fitzgerald, K.A. DNA sensing by the cGAS-STING pathway in health and disease. Nat. Rev. Genet. 2019, 20, 657-674. [CrossRef]

81. Li, T.; Chen, Z.J. The cGAS-cGAMP-STI NG pathway connects DNA damage to inflammation, senescence, and cancer. J. Exp. Med. 2018, 215, 1287-1299. [CrossRef]

82. Glück, S.; Guey, B.; Gulen, M.F.; Wolter, K.; Kang, T.W.; Schmacke, N.A.; Bridgeman, A.; Rehwinkel, J.; Zender, L.; Ablasser, A. Innate immune sensing of cytosolic chromatin fragments through cGAS promotes senescence. Nat. Cell Biol. 2017, 19, 1061-1070. [CrossRef] [PubMed]

83. Yang, H.; Wang, H.; Ren, U.; Chen, Q.; Chena, Z.J. CGAS is essential for cellular senescence. Proc. Natl. Acad. Sci. USA 2017, 114, E4612-E4620. [CrossRef]

84. Dou, Z.; Ghosh, K.; Vizioli, M.G.; Zhu, J.; Sen, P.; Wangensteen, K.J.; Simithy, J.; Lan, Y.; Lin, Y.; Zhou, Z.; et al. Cytoplasmic chromatin triggers inflammation in senescence and cancer. Nature 2017, 550, 402-406. [CrossRef]

85. Forsberg, L.A.; Gisselsson, D.; Dumanski, J.P. Mosaicism in health and disease-Clones picking up speed. Nat. Rev. Genet. 2017, 18, 128-142. [CrossRef] [PubMed]

86. Dou, Y.; Gold, H.D.; Luquette, L.J.; Park, P.J. Detecting Somatic Mutations in Normal Cells. Trends Genet. 2018, 34, 545-557. [CrossRef]

87. Lidzbarsky, G.; Gutman, D.; Shekhidem, H.A.; Sharvit, L.; Atzmon, G. Genomic instabilities, cellular senescence, and aging: In vitro, in vivo and aging-like human syndromes. Front. Med. 2018, 5, 104. [CrossRef] [PubMed]

88. Olivieri, F.; Albertini, M.C.; Orciani, M.; Ceka, A.; Cricca, M.; Procopio, A.D.; Bonafè, M. DNA damage response (DDR) and senescence: Shuttled inflamma-miRNAs on the stage of inflamm-aging. Oncotarget 2015, 6, 35509-35521. [CrossRef] [PubMed]

89. Slieker, R.C.; van Iterson, M.; Luijk, R.; Beekman, M.; Zhernakova, D.V.; Moed, M.H.; Mei, H.; van Galen, M.; Deelen, P.; Bonder, M.J.; et al. Age-related accrual of methylomic variability is linked to fundamental ageing mechanisms. Genome Biol. 2016, 17, 191. [CrossRef]

90. Blasiak, J.; Arabski, M.; Krupa, R.; Wozniak, K.; Zadrozny, M.; Kasznicki, J.; Zurawska, M.; Drzewoski, J. DNA damage and repair in type 2 diabetes mellitus. Mutat. Res. Fundam. Mol. Mech. Mutagen. 2004, 554, 297-304. [CrossRef]

91. Coppede, F.; Migliore, L. DNA Damage and Repair in Alzheimers Disease. Curr. Alzheimer Res. 2009, 6, 36-47. [CrossRef]

92. Franceschi, C.; Garagnani, P.; Vitale, G.; Capri, M.; Salvioli, S. Inflammaging and 'Garb-aging'. Trends Endocrinol. Metab. 2017, 28, 199-212. [CrossRef] [PubMed]

93. Ishida, T.; Ishida, M.; Tashiro, S.; Yoshizumi, M.; Kihara, Y. Role of DNA Damage in Cardiovascular Disease. Circ. J. 2014, 78, 42-50. [CrossRef] [PubMed]

94. O'Connor, M.J. Targeting the DNA Damage Response in Cancer. Mol. Cell 2015, 60, 547-560. [CrossRef] [PubMed]

95. Marsman, G.; Zeerleder, S.; Luken, B.M. Extracellular histones, cell-free DNA, or nucleosomes: Differences in immunostimulation. Cell Death Dis. 2016, 7, e2518. [CrossRef] [PubMed]

96. Van Nieuwenhuijze, A.E.M.; Van Lopik, T.; Smeenk, R.J.T. Time between onset of apoptosis and release of nucleosomes from apoptotic cells: Putative implications for systemic lupus erythematosus. Ann. Rheum. Dis. 2003, 62, 10-14. [CrossRef] [PubMed]

97. Holdenrieder, S.; Stieber, P.; Bodenmüller, H.; Fertig, G.; Fürst, H.; Schmeller, N.; Untch, M.; Seidel, D. Nucleosomes in serum as a marker for cell death. Clin. Chem. Lab. Med. 2001, 39, 596-605. [CrossRef]

98. Holdenrieder, S.; Stieber, P.; Chan, L.Y.S.; Geiger, S.; Kremer, A.; Nagel, D.; Lo, Y.M.D. Cell-free DNA in serum and plasma: Comparison of ELISA and quantitative PCR. Clin. Chem. 2005, 51, 1544-1546. [CrossRef]

99. Mittra, I.; Pal, K.; Pancholi, N.; Tidke, P.; Siddiqui, S.; Rane, B.; D'souza, J.; Shaikh, A.; Parab, S.; Shinde, S.; et al. Cell-free chromatin particles released from dying host cells are global instigators of endotoxin sepsis in mice. PLoS ONE 2020, 15, e0229017. [CrossRef]

100. Babayan, A.; Pantel, K. Advances in liquid biopsy approaches for early detection and monitoring of cancer. Genome Med. 2018, 10, 1-3. [CrossRef]

101. Mittra, I.; Pal, K.; Pancholi, N.; Shaikh, A.; Rane, B.; Tidke, P.; Kirolikar, S.; Khare, N.K.; Agrawal, K.; Nagare, H.; et al. Prevention of chemotherapy toxicity by agents that neutralize or degrade cell-free chromatin. Ann. Oncol. Off. J. Eur. Soc. Med. Oncol. 2017, 28, 2119-2127. [CrossRef]

102. Subramaniam, S.; Vohra, I.; Iyer, A.; Nair, N.K.; Mittra, I. A paradoxical synergism between Resveratrol and copper (II) with respect to degradation of DNA and RNA. F1000Research 2015, 4, 1145. [CrossRef] [PubMed]

103. Burns, J.; Yokota, T.; Ashihara, H.; Lean, M.E.J.; Crozier, A. Plant foods and herbal sources of resveratrol. J. Agric. Food Chem. 2002, 50, 3337-3340. [CrossRef] [PubMed]

104. De Romaña, D.L.; Olivares, M.; Uauy, R.; Araya, M. Risks and benefits of copper in light of new insights of copper homeostasis. J. Trace Elem. Med. Biol. 2011, 25, 3-13. [CrossRef] [PubMed] 